Analytical Chemistry

Laboratory

ANL/ACL-95/1

Analytical Chemistry

Laboratory

Analytical Chemistry

Laboratory

Analytical Chemistry

Laboratory

Analytical Chemistry

Laboratory

Analytical Chemistry

Laboratory

Analytical Chemistry

Laboratory

Analytical Chemistry

Preparation of Waste Oil for Analysis to Determine Hazardous Metals

Laboratory

Analytical Chemistry

Laboratory

Analytical Chemistry

Laboratory

Analytical Chemistry

Laboratory

Analytical Chemistry

Laboratory

Analytical Chemistry

Laboratory

Analytical Chemistry

Laboratory

Analytical Chemistry

Laboratory

Analytical Chemistry

Laboratory

Analytical Chemistry

Laboratory

by A. M. Essling, D. R. Huff, E. A. Huff, I. M. Fox, and D. G. Graczyk

Chemical Technology Division

Argonne National Laboratory, Argonne, Illinois 60439

operated by The University of Chicago

for the United States Department of Energy under Contract W-31-109-Eng-38

Analytical Chemistry

Laboratory

Analytical Chemistry

Laboratory

Analytical Chemistry

Laboratory

Analytical Chemistry

Laboratory 
Argonne National Laboratory, with facilities in the states of Illinois and Idaho, is owned by the United States government, and operated by The University of Chicago under the provisions of a contract with the Department of Energy.

\section{DISCLAIMER}

This report was prepared as an account of work sponsored by an agency of the United States Government. Neither the United States Government nor any agency thereof, nor any of their employees, makes any warranty, express or implied, or assumes any legal liability or responsibility for the accuracy, completeness, or usefulness of any information, apparatus, product, or process disclosed, or represents that its use would not infringe privately owned rights. Reference herein to any specific commercial product, process, or service by trade name, trademark, manufacturer, or otherwise, does not necessarily constitute or imply its endorsement, recommendation, or favoring by the United States Government or any agency thereof. The views and opinions of authors expressed herein do not necessarily state or reflect those of the United States Government or any agency thereof.

Reproduced from the best available copy.

Available to DOE and DOE contractors from the

Office of Scientific and Technical Information

$$
\text { P.O. Box } 62
$$

Oak Ridge, TN 37831

Prices available from (615) 576-8401

Available to the public from the

National Technical Information Service

U.S. Department of Commerce

5285 Port Royal Road

Springfield, VA 22161 


\section{DISCLAIMER}

Portions of this document may be illegible in electronic image products. Images are produced from the best available original document. 
ANL/ACL-95/1

\author{
Argonne National Laboratory \\ 9700 South Cass Avenue \\ Argonne, IL 60439
}

\title{
PREPARATION OF WASTE OIL FOR ANALYSIS \\ TO DETERMINE HAZARDOUS METALS
}

by

Alice M. Essling, Doris R. Huff, Edmund A. Huff, Irene M. Fox, and Donald G. Graczyk

\author{
Analytical Chemistry Laboratory \\ Chemical Technology Division
}

July 1995

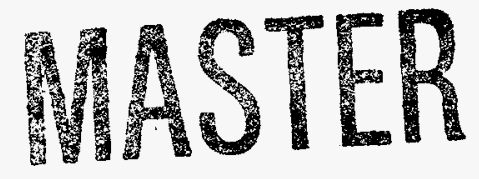

DISTRIBUTION OF THIS DOCUMENT IS UNLIMITEP 
ABSTRACT 1

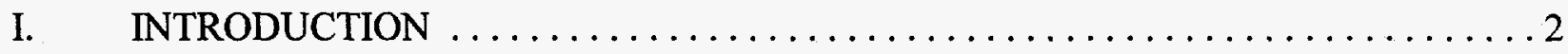

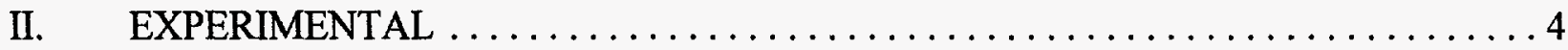

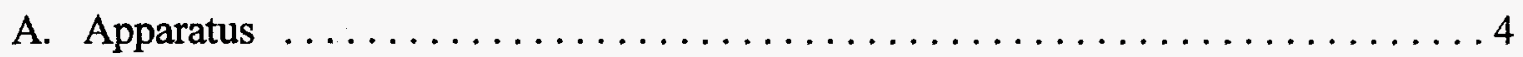

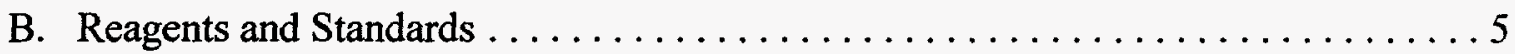

III. SAMPLE PREPARATION AND ANALYSIS $\ldots \ldots \ldots \ldots \ldots \ldots \ldots \ldots \ldots \ldots \ldots$

A. Parr Oxygen Bomb Combustion $\ldots \ldots \ldots \ldots \ldots \ldots \ldots \ldots \ldots \ldots$

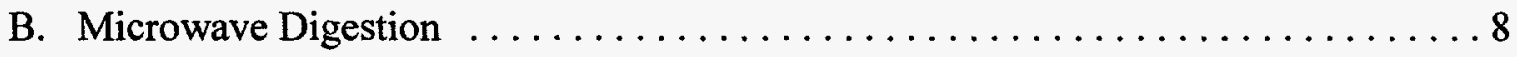

IV. DISCUSSION AND CONCLUSIONS $\ldots \ldots \ldots \ldots \ldots \ldots \ldots \ldots \ldots \ldots \ldots \ldots \ldots \ldots \ldots$

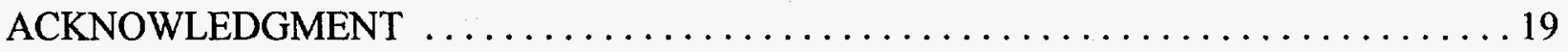

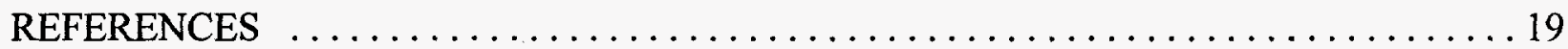




\section{LIST OF TABLES}

No.

Title

Page

1. Recovery of Metals from Parr Oxygen Bomb Combustion of Conostan Oil S-21,

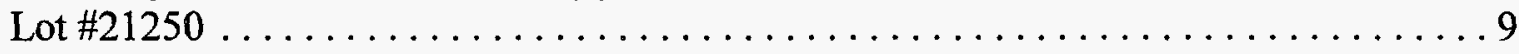

2. Recovery of Mercury from Parr Oxygen Bomb Combustion of Oil Reference Materials

3. Microwave System Control-Program Variables (First Heating Cycle) $\ldots \ldots \ldots \ldots \ldots 11$

4. Microwave System Control-Program Variables (Second Heating Cycle) $\ldots \ldots \ldots \ldots 12$

5. Recovery of Metals from Microwave Digestion of Conostan Oil S-21,

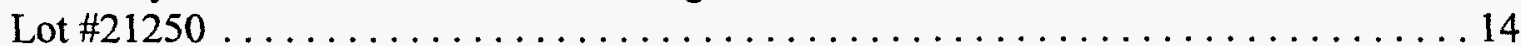

6. Recovery of Arsenic from Microwave Digestion of Conostan Oil Arsenic,

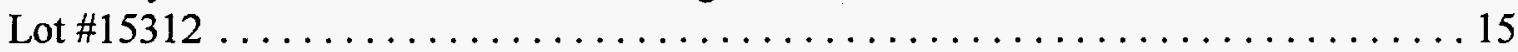

7. Recovery of Mercury from Microwave Digestion of Oil Reference Materials ....... 16

8. Recovery of Selenium from Microwave Digestion of Conostan Oil Selenium, Lot \#12013... 


\title{
PREPARATION OF WASTE OIL FOR ANALYSIS \\ TO DETERMINE HAZARDOUS METALS
}

by

\author{
Alice M. Essling, Doris R. Huff, Edmund A. Huff, \\ Irene M. Fox, and Donald G. Graczyk
}

\begin{abstract}
Two methods for preparing waste-oil samples to permit measurement of their metals content were evaluated. For this evaluation, metals-in-oil standard reference materials were prepared by each method and the resulting solutions were analyzed for 20 metals, including those ( $\mathrm{As}, \mathrm{Ba}, \mathrm{Cd}, \mathrm{Cr}, \mathrm{Pb}, \mathrm{Hg}, \mathrm{Se}$, and $\mathrm{Ag}$ ) regulated as hazardous under the Resource Conservation and Recovery Act. One preparation method involved combustion of the waste oil under oxygen at 25 atm pressure, as described in the American Society for Testing and Materials test method E926-88. As we applied it, this method gave recoveries well under $90 \%$ for most of the metals that we examined and, hence, proved unsatisfactory for routine application to wasteoil analysis. With the other method, nitric acid decomposition in a sealed vessel heated with microwave energy (analogous to U.S. Environmental Protection Agency Method 3051), recoveries of all 20 metal contaminants were within 90 to $110 \%$ of the certified values. This microwave digestion procedure was also more efficient since it allowed six samples to be prepared together, whereas the oxygen combustion approach allowed processing of only one sample at a time.
\end{abstract}




\section{INTRODUCTION}

Many research and development programs at Department of Energy laboratories depend on vacuum pumps, hydraulic systems, or lubricated machines, which contain oil that needs changing and, ultimately, disposal. Proper disposal of oil requires a determination as to whether it is contaminated with metals (e.g., $\mathrm{As}, \mathrm{Ba}, \mathrm{Cd}, \mathrm{Cr}, \mathrm{Hg}, \mathrm{Pb}, \mathrm{Se}, \mathrm{Ag}$ ) that are regulated as hazardous under the Resource Conservation and Recovery Act (RCRA) and/or radionuclides. Because commonly used techniques for measuring metal contaminants perform best with aqueous samples, we undertook a study of methods for decomposing oils in order to identify a method that would provide a single aqueous solution compatible with the most frequently used techniques, including inductively coupled plasma-atomic emission spectrometry (ICP-AES), graphite furnace atomic absorption spectrophotometry (GFAA), and cold vapor atomic absorption spectrophotometry (CVAA). Such a solution might also have advantages for radiological measurements including those by liquid scintillation or by proportional counting to determine gross alpha or beta radioactivity.

In evaluating the performance of a sample-preparation technique, we considered the following qualities to be important: (1) thorough sample decomposition, (2) retention of volatile analytes, (3) acceptable analyte recovery, (4) minimal contamination from the environment or the digestion vessel, (5) low reagent blanks, and (6) speed. We investigated two preparation techniques with respect to these criteria. One involved combustion of the waste oil under oxygen at $25 \mathrm{~atm}$ pressure, as described in the ASTM test method E926-88 [1]. The other was nitric acid decomposition of the oil in a sealed vessel heated with microwave energy, in a manner analogous to that of U.S. EPA Method 3051 [2]. Equipment for both preparation methods of preparation was available in the Analytical Chemistry Laboratory (ACL) at Argonne National Laboratory (ANL). 
This report describes the results of applying these methods to oil reference materials containing metal analytes of general interest. The accuracy of each method is evaluated by comparing the amount of each analyte recovered to the amount of analyte expected. After sample preparation, metals other than mercury were determined using ICP-AES or GFAA. Mercury was determined in the same solution by CVAA. No oil standard containing radionuclides was available for this study. However, we anticipate that many radionuclides will exhibit dissolution behavior similar to that of metals we studied, and that any preparative technique that performs well for metal determinations will also be useful for radiological measurements. 


\section{EXPERIMENTAL}

\section{A. Apparatus}

1. Parr Oxygen Bomb

a. Parr Oxygen Bomb unit, Model 101A or equivalent (Parr Instrument Co., Moline, IL)

b. Parr Oxygen Bomb ignition unit

c. Parr Oxygen Bomb platinum fuse wire $\left(0.005^{\prime \prime}\right.$ dia)

d. Parr Oxygen Bomb quartz liner and sample cup

2. Oxygen tank with two-stage regulator to deliver gas to $25 \mathrm{~atm}$

3. Laboratory thermometer - nonmercury type. A range of 0 to 50 degrees Celsius is sufficient.

4. Water bath

5. Microwave System

a. Microwave Oven - 950 watt or 630 watt, pressure-controlled, programmable. Model CEM MDS2100 (CEM Corp., Matthews, NC) or equivalent.

b. Vessels - Teflon-lined digestion vessels with one control vessel for pressure feedback control (CEM Corp., Part No. 323010, now replaced by Advanced Composite Vessel/Sleeve Assemblies, Part No. 327011). The outer body and cap consist of microwave-transparent Ultem polyetherimide. The removable liner, the liner cover, and safety rupture membrane are of Teflon PFA. A plastic vent stem allows the vessel to be vented to remove residual gas pressure. Gases escape through the exhaust port if the safety rupture membrane ruptures or if the vessel is hand 
vented. The liner cover of the control vessel is equipped with a Teflon PFA adaptor to allow for a pressure-tubing connection for pressure measurements. These vessel assemblies are rated for use at pressures up to 200 psig and temperatures to $250^{\circ} \mathrm{C}$.

6. Analytical balances

7. Volumetric flasks - usually $50-\mathrm{mL}$ and $100-\mathrm{mL}$ capacity

B. Reagents and Standards

1. Nitric Acid $\left(\mathrm{HNO}_{3}\right)$ - concentrated and $10 \%$ solution. Instra-Analyzed acid (Baker Chemical Co.) was used throughout this study.

2. Standard Reference Materials (SRM)

a. Wear-Metals in Lubricating Oil (National Institute of Standards and Technology, Gaithersburg, MD)

SRM 1083 - Base Oil standard

SRM 1084a - Nominally $100 \mu \mathrm{g}$ analyte per $\mathrm{g}$ of oil; certified levels of $\mathrm{Al}, \mathrm{Ag}, \mathrm{Cr}, \mathrm{Cu}, \mathrm{Fe}, \mathrm{Mg}, \mathrm{Mo}, \mathrm{Ni}, \mathrm{Pb}, \mathrm{Sn}, \mathrm{Ti}, \mathrm{V}, \mathrm{S}, \mathrm{Si}$

SRM 1085a - Nominally $300 \mu$ g analyte/g; same metals as SRM 1084a

b. Metallo-Organic Standards (Conostan Division, Conoco Specialty

Products Inc., Ponca City, OK)

Conostan S-21 - Nominally 900 ppm by weight of $\mathrm{Al}, \mathrm{Ag}, \mathrm{B}, \mathrm{Ba}, \mathrm{Be}$, $\mathrm{Cd}, \mathrm{Cr}, \mathrm{Cu}, \mathrm{Fe}, \mathrm{Mg}, \mathrm{Mn}, \mathrm{Mo}, \mathrm{P}, \mathrm{Na}, \mathrm{Ni}, \mathrm{Pb}, \mathrm{Si}, \mathrm{Sn}, \mathrm{Ti}, \mathrm{V}, \mathrm{Zn}$

Conostan As - nominally 100 ppm As

Conostan Se - nominally 100 ppm Se

Conostan $\mathrm{Hg} \quad$ - nominally $100 \mathrm{ppm} \mathrm{Hg}$ 


\section{SAMPLE PREPARATION AND ANALYSIS}

\section{A. Parr Oxygen Bomb Combustion - Preparation Method and Analysis Results}

The organic matter of samples may be destroyed in an oxygen combustion bomb. The oxidized form of metals are absorbed (trapped) in an acid solution, which can then be analyzed for the metals of interest.

The procedure for the Parr Oxygen Bomb combustion was as follows [3].

- Weigh up to 1-g of an oil into a quartz combustion cup.

- Place the combustion cup in the vessel holder.

- Thread a 10-cm platinum fuse wire so that the loop of the wire is positioned slightly above, or just barely touching the surface of the oil.

- Add about $10 \mathrm{~mL}$ of a $10 \% \mathrm{HNO}_{3}$ solution to the quartz liner of the cylinder bomb jacket.

- Assemble the bomb, seal, and fill with oxygen to $25(+1)$ atm. The bomb must NOT be overcharged.

NOTE: The oxygen filling system shall include a pressure regulator or other automatic device to prevent overcharging beyond the maximum allowable pressure specified in ASTM Method E926-88. There must be no oil or other combustibles in the regulator system. The bomb must NOT be fired if an overcharge of oxygen should be accidentally admitted. Care must be taken not to upset or disturb the sample during the assembly process.

- Place the bomb in the water bath, a larger vessel filled with distilled water at approximately ambient temperature. Check for evidence of gas leakage.

NOTE: The bomb must be completely submerged in the water during the firing and the charge must NOT be ignited if there is any evidence of gas leakage. 
- Attach the Parr ignition unit electrodes by plugging into the channels located at the top of the unit.

- Place a nonmercury thermometer in contact with the top of the bomb unit while it is submerged in the water bath. Note the temperature.

- Initiate the combustion process by depressing the switch on the Parr ignition unit. NOTE: The Parr ignition unit draws the ignition current from a step-down transformer, using the lowest practical voltage recommended by the manufacturer. The circuit is controlled by a double-pole push switch that can be closed only when the operator presses the ignition button. Alternative ignition units must incorporate these features.

- After a few minutes, observe any rise in the temperature of the water bath. A temperature increase is an indication that the bomb has fired.

- Allow the water bath to cool to approximately the starting temperature.

- When cooling has occurred, remove the ignition electrodes and the bomb unit from the water bath.

- Dry off the entire unit using paper towels.

- Slowly open the vent at the top of the unit until the pressure has equilibrated to atmospheric.

Open the bomb unit and quantitatively transfer the nitric acid solution to a volumetric flask. Rinse all surfaces on the inside of the unit with water and add the rinse water to the flask volume.

NOTE: Usually when a $1-\mathrm{g}$ sample is combusted, it is diluted to $100 \mathrm{~mL}$. When the bomb unit is opened, the contents should be inspected to determine whether the combustion was complete. If unreacted sample remains, the contents should be discarded and another sample portion processed. 
- The diluted solution has an approximate acid concentration of $1 \%$ in $\mathrm{HNO}_{3}$. The sample is now ready for analysis by ICP-AES, GFAA, or CVAA, to determine metals content of the decomposed oil.

The performance of this procedure was tested using SRMs that contained certified concentrations of specified metals in an oil matrix. The SRMs Conostan S-21 contains 21 analytes, including the RCRA metals $\mathrm{Ba}, \mathrm{Cd}, \mathrm{Cr}, \mathrm{Pb}$, and $\mathrm{Ag}$. The other RCRA metals (As, $\mathrm{Se}$, and $\mathrm{Hg}$ ) were available from individual standard Conostan oils, including Conostan As, Conostan Se, and Conostan Hg. Wear-Metals in Lubricating Oil standards from the National Institute of Standards and Technology were used only in preliminary and early work because they contain only the three RCRA metals $(\mathrm{Ag}, \mathrm{Cr}$, and $\mathrm{Pb})$ of most concern in automotive or machine tool applications.

The results of analyses of solutions from the combustion of the standard oils are given in Tables 1 and 2.

\section{B. Microwave Digestion - Preparation Method and Analysis Results}

Nitric acid digestion at elevated pressures and temperatures, performed in closed vessels heated by microwave power, rapidly destroys the organic matrix of oil samples [2]. Modern laboratory microwave systems allow controlled, uniform application of microwave power and pressure and/or temperature monitoring, thus providing reproducible conditions while not exceeding the pressure or temperature limitations of the specially designed Teflon sample containers $[4,5]$. 
Table 1. Recovery of Metals from Parr Oxygen Bomb Combustion of Conostan Oil S-21, Lot \#21250 ${ }^{\mathrm{a}}$

\begin{tabular}{|c|c|c|c|c|c|c||}
\hline \multicolumn{7}{|c|}{ Recovery, \% } \\
\hline & $\mathrm{Al}$ & $\mathrm{Ba}$ & $\mathrm{Ca}$ & $\mathrm{Cd}$ & $\mathrm{Cr}$ & $\mathrm{Cu}$ \\
\hline Run 1 & 14.8 & 3.5 & 26.7 & 88.4 & 4.4 & 24.4 \\
\hline Run 2 & 21.4 & 3.1 & 43.7 & 92.2 & 5.1 & 42.4 \\
\hline \hline & \multicolumn{7}{|c|}{ Recovery, \% } & & \\
\hline & $\mathrm{Fe}$ & $\mathrm{Mg}$ & $\mathrm{Mn}$ & $\mathrm{Ni}$ & $\mathrm{Pb}$ & $\mathrm{V}$ \\
\hline Run 1 & 8.0 & 21.3 & 20.0 & 7.6 & 48.9 & 19.6 \\
\hline Run 2 & 13.9 & 33.1 & 31.2 & 13.7 & 51.0 & 29.2 \\
\hline \hline & & & Recovery, \% & & \\
\hline \hline & $\mathrm{Zn}$ & $\mathrm{B}$ & $\mathrm{Mo}$ & $\mathrm{Ti}$ & & \\
\hline Run 1 & 61.1 & 71.3 & 35.7 & 4.0 & & \\
\hline Run 2 & 63.9 & 74.9 & 50.0 & 7.8 & & \\
\hline \hline
\end{tabular}

a Standard metal concentrations $=900 \mu \mathrm{g} / \mathrm{g}$.

b Determined by ICP-AES.

Table 2. Recovery of Mercury from Parr Oxygen Bomb Combustion of Oil Reference Materials

\begin{tabular}{||c|c|c|c||}
\hline \multirow{2}{*}{ Reference Material } & \multicolumn{3}{|c|}{ Mercury } \\
\cline { 2 - 4 } & Standard conc., $\boldsymbol{\mu g} / \mathbf{g}$ & Measured conc., $\boldsymbol{\mu g} / \mathbf{g}$ & Recovery, \% \\
\hline \hline $\begin{array}{c}\text { Conostan Hg } \\
\text { Oil Lot \#13015 }\end{array}$ & 100 & Run 1: 75.9 & Run 1: 76 \\
\cline { 2 - 4 } & & Run 2:83.3 & Run 2: 83 \\
\hline $\begin{array}{c}\text { Conostan Hg } \\
\text { Oil Lot \#109 }\end{array}$ & 100 & Run 1:72.8 & Run 1: 73 \\
\hline NBS 1083 Blank & & Run 2: 78.5 & Run 2: 78 \\
\hline
\end{tabular}

a Determined by CVAA with uncertainty of $\pm 10 \%$. 
Our procedure for preparing standard oils and waste oil samples by microwave-assisted digestion was based on U.S. EPA Method 3051[2]. Our procedure was designed to accommodate handling six vessels at one time. It comprised the following operations:

- Weigh up to $0.5 \mathrm{~g}$ of oil into the Teflon liner of a CEM microwave digestion vessel.

NOTE: When digesting organic materials with $\mathrm{HNO}_{3}$ in a closed vessel, considerable pressure is produced by gaseous byproducts, such as $\mathrm{CO}_{2}, \mathrm{NO}, \mathrm{NO}_{2}$, and $\mathrm{H}_{2} \mathrm{O}$. It is, therefore, necessary to limit the amount of sample used.

- Add $10 \mathrm{~mL}$ concentrated $\mathrm{HNO}_{3}$.

NOTE: A total of six vessels was always used. Any that did not contain a sample were included with $10 \mathrm{~mL}$ of $\mathrm{HNO}_{3}$ only. We did not determine whether more or fewer vessels could be safely handled in the microwave system.

- Place each liner in a vessel body. Assemble and close the vessel, hand-tightening the cover and the vent stem. Attach the control vessel cap to the vessel containing the largest amount of sample by weight.

NOTE: Ensure that a new Teflon rupture membrane is in place in the liner cover of each vessel.

- Optional : Weigh the entire sealed vessel and record the weight to the nearest $0.02 \mathrm{~g}$. Usually, the weight is approximately $300 \mathrm{~g}$.

- Place the vessels on the microwave turntable, evenly spaced, and attach the pressure line to the control vessel.

- Turn ON the microwave oven following the manufacturer's instructions [4].

- Access the file named OIL from the memory. If not available, enter the microwave heating parameters shown in Table 3. 
Table 3. Microwave System Control-Program Variables ${ }^{a}$ (First Heating Cycle)

\begin{tabular}{||c|c|c|c|c|c||}
\hline \multicolumn{5}{|c|}{$\begin{array}{c}\text { File Name: Oil } \\
\text { Inorganic Sample Digestion }\end{array}$} \\
\hline \hline Stage & $(1)$ & $(2)$ & $(3)$ & $(4)$ & $(5)$ \\
\hline Power, \% & $60 \%$ & $60 \%$ & $60 \%$ & $60 \%$ & $60 \%$ \\
\hline Pressure, psig & 40 & 85 & 135 & 200 & 200 \\
\hline Run Time, min & $15: 00$ & $15: 00$ & $15: 00$ & $15: 00$ & $15: 00$ \\
\hline Time @ P, min & $05: 00$ & $05: 00$ & $10: 00$ & $20: 00$ & $20: 00$ \\
\hline $\begin{array}{l}\text { Temperature } \\
\text { NA }\end{array}$ & $100 \%$ & $100 \%$ & $100 \%$ & $100 \%$ & NA \\
\hline $\begin{array}{l}\text { Fan Speed, \% } \\
\text { Number of Vessels: } 6\end{array}$ \\
$\begin{array}{l}\text { Volume Per Vessel: } 10 \mathrm{~mL} \\
\text { Sample Weight: } 0.5 \mathrm{~g} \\
\text { Acid: HNO } \\
60 \% \text { Power }=295 \text { Watts }\end{array}$
\end{tabular}

a Variables were selected using guidance from Ref. 6.

b Not applicable.

- Heat according to the scheme in Table 3 to digest the samples.

NOTE: Organic matrices require multiple pressure control points to control reaction rates and to avoid runaway digestions.

- Allow the vessels to cool to room temperature in place.

- Wearing vinyl or latex gloves, remove the vessels and carefully vent in a fume hood by slowly opening the vent stem.

- Retighten the vent stem and return the vessels to the microwave oven.

- Heat again, accessing the file name OIL2. If this program is not in the memory, enter the microwave heating parameters shown in Table 4. 
Table 4. Microwave System Control-Program Variables (Second Heating Cycle)

\begin{tabular}{||c|c|c|c||}
\hline \multicolumn{4}{|c|}{$\begin{array}{c}\text { File Name: Oil 2 } \\
\text { Inorganic Sample Digestion }\end{array}$} \\
\hline Stage & $(1)$ & $(2)$ & $(3)$ \\
\hline Power, \% & 65 & 65 & 65 \\
\hline Pressure, psig & 100 & 150 & 150 \\
\hline Run Time, min & $15: 00$ & $15: 00$ & $15: 00$ \\
\hline Time @ P, min & $10: 00$ & $20: 00$ & $20: 00$ \\
\hline Temperature & NA $^{\mathrm{a}}$ & NA & NA \\
\hline \multicolumn{1}{|c|}{ Fan Speed, \% } & 100 & 100 & 100 \\
\hline $\begin{array}{l}\text { Number of Vessels: } 6 \\
\text { Volume Per Vessel: } 10 \mathrm{~mL} \\
\text { Sample Weight: } 0.5 \mathrm{~g} \\
\text { Acid: } \mathrm{HNO}_{3} \\
65 \% \text { Power }=350 \text { Watts }\end{array}$ & & \\
\hline
\end{tabular}

${ }^{\text {a }}$ Not applicable.

- At the end of the heating period, allow the vessels to cool to room temperature in place.

- Remove the vessels from the microwave system. Optional: Weigh each vessel assembly to the nearest 0.02 grams and record the weights.

NOTE: If the weight of the acid plus sample has decreased by more than about $10 \%$ from the original weight, determine the reason for the weight loss. Once the source of the loss has been corrected, prepare a new sample.

- Wearing vinyl or latex gloves, carefully vent and uncap each vessel in a fume hood. 
- Quantitatively transfer the sample to a volumetric flask (usually $50-\mathrm{mL}$ or $100-$ $\mathrm{mL}$ capacity) using water to rinse the Teflon liner and cap. Dilute to volume. NOTE: On dilution with water, these solutions are slightly cloudy; however, this does not seem to adversely affect the performance of analyses to be done [6].

- The diluted digestate has an approximate acid concentration of $10-20 \% \mathrm{HNO}_{3}$. This digestate is now ready to be analyzed for the RCRA metals and any other elements of interest by ICP-AES, GFAA, or CVAA.

Results of analyses after microwave-assisted digestion of oil reference materials are shown in Tables $5,6,7$, and 8 . 
Table 5. Recovery of Metals from Microwave Digestion of Conostan Oil S-21, Lot \#21250

\begin{tabular}{||c|c|c|c|c|c|c||}
\hline \multirow{2}{*}{ Trial } & \multicolumn{6}{|c|}{ Recovery, \% $^{\mathrm{b}}$} \\
\cline { 2 - 8 } & $\mathrm{Al}$ & $\mathrm{Ba}$ & $\mathrm{Ca}$ & $\mathrm{Cd}$ & $\mathrm{Cr}$ & $\mathrm{Cu}$ \\
\hline Run 1 & 102.4 & 93.2 & 103.4 & 94.3 & 96.8 & 96.9 \\
\hline Run 2 & 109.2 & 95.1 & 117.8 & 96.4 & 98.8 & 97.9 \\
\hline Run 3 & 104.1 & 95.2 & 100.9 & 96.6 & 98.4 & 102.3 \\
\hline Run 4 & 103.3 & 97.4 & 102.2 & 99.0 & 101.1 & 99.7 \\
\hline Run 5 & 116.6 & 97.2 & $133.7^{\mathrm{c}}$ & 99.0 & 101.0 & 98.8 \\
\hline Run 6 & 105.2 & 98.4 & 105.4 & 100.0 & 102.3 & 100.2 \\
\hline Run 7 & 98.4 & 91.2 & 92.1 & 92.8 & 94.6 & 98.2 \\
\hline Run 8 & 101.7 & 93.7 & 99.7 & 94.9 & 96.9 & 98.7 \\
\hline Mean & 105.1 & 95.2 & 103.1 & 96.6 & 98.7 & 99.1 \\
\hline Std. Dev. & 5.6 & 2.4 & 7.7 & 2.6 & 2.6 & 1.6 \\
\hline \hline & & & \multicolumn{7}{|c||}{ Recovery, \% ${ }^{\mathrm{b}}$} & & \\
\cline { 2 - 9 } Trial & $\mathrm{Fe}$ & $\mathrm{Mg}$ & $\mathrm{Mn}$ & $\mathrm{Ni}$ & $\mathrm{Pb}$ & $\mathrm{V}$ \\
\hline \hline Run 1 & 93.0 & 95.9 & 96.3 & 93.9 & 96.6 & 94.1 \\
\hline Run 2 & 95.1 & 98.1 & 98.1 & 95.8 & 98.1 & 95.8 \\
\hline Run 3 & 94.8 & 98.4 & 98.4 & 96.1 & 98.9 & 95.9 \\
\hline Run 4 & 97.2 & 100.6 & 100.6 & 98.1 & 100.9 & 98.3 \\
\hline Run 5 & 97.0 & 101.0 & 100.1 & 97.7 & 101.0 & 97.9 \\
\hline Run 6 & 98.2 & 101.9 & 101.4 & 99.1 & 102.6 & 99.3 \\
\hline Run 7 & 91.7 & 94.8 & 94.6 & 92.8 & 95.7 & 91.9 \\
\hline Run 8 & 93.7 & 96.9 & 96.7 & 94.7 & 97.6 & 94.3 \\
\hline Mean & 95.1 & 98.4 & 98.3 & 96 & 98.9 & 95.9 \\
\hline Std. Dev. & 2.2 & 2.5 & 2.3 & 2.2 & 2.4 & 2.5 \\
\hline
\end{tabular}


Table 5. Recovery of Metals from Microwave Digestion of Conostan Oil S-21, Lot \#21250 ${ }^{\mathrm{a}}$ (cont'd.)

\begin{tabular}{||c|c|c|c|c|c||}
\hline \multirow{2}{*}{ Trial } & \multicolumn{5}{|c||}{ Recovery, \% $^{\mathbf{b}}$} \\
\cline { 2 - 6 } & $\mathrm{Zn}$ & $\mathrm{Ag}$ & $\mathrm{B}$ & $\mathrm{Mo}$ & $\mathrm{Ti}$ \\
\hline Run 1 & 97.3 & 102.9 & 89.3 & 97.1 & 94.1 \\
\hline Run 2 & 98.8 & 103.6 & 92.0 & 97.0 & 95.1 \\
\hline Run 3 & 102.6 & 104.3 & 90.4 & 98.0 & 92.7 \\
\hline Run 4 & 99.7 & 104.1 & 93.2 & 96.7 & 94.4 \\
\hline Run 5 & 99.0 & 103.9 & 94.4 & 95.6 & 94.7 \\
\hline Run 6 & 100.2 & 104.6 & 92.9 & 99.8 & 94.7 \\
\hline Run 7 & 98.2 & 104.2 & 92.7 & 97.0 & 96.1 \\
\hline Run 8 & 98.7 & 100.1 & 89.9 & 93.9 & 95.1 \\
\hline Mean & 99.3 & 103.5 & 92.0 & 96.9 & 94.6 \\
\hline Std. Dev. & 1.6 & 1.4 & 1.9 & 1.7 & 1.0 \\
\hline \hline
\end{tabular}

a Standard metal concentrations $=900 \mu \mathrm{g} / \mathrm{g}$.

b Determined by ICP-AES using matrix-matched standards calibration.

c Excluded from calculation of mean and standard deviation.

Table 6. Recovery of Arsenic from Microwave Digestion of Conostan Oil Arsenic, Lot \#15312

\begin{tabular}{|c|c|c|}
\hline \multirow{2}{*}{ Trial } & \multicolumn{2}{|c|}{ Arsenic Recovery, \% } \\
\cline { 2 - 3 } & ICP-AES $^{\mathrm{b}}$ & GFAA $^{\mathrm{c}}$ \\
\hline Run 1 & 96.2 & 93.9 \\
\hline Run 2 & 97.6 & 91.8 \\
\hline Run 3 & 104 & 97.5 \\
\hline Mean & 99.3 & 94.4 \\
\hline Std. Dev. & 4.2 & 2.9 \\
\hline
\end{tabular}

a Standard arsenic concentrations $=100 \mu \mathrm{g} / \mathrm{g}$.

${ }^{\mathrm{b}}$ Determined with ICP-AES using matrix-matched standards calibration.

${ }^{c}$ Determined with GFAA. 
Table 7. Recovery of Mercury from Microwave Digestion of Oil Reference Materials

\begin{tabular}{|c|c|c|c|}
\hline \multirow[b]{2}{*}{$\begin{array}{c}\text { Reference } \\
\text { Material } \\
\end{array}$} & \multicolumn{3}{|c|}{ Mercury } \\
\hline & $\begin{array}{c}\text { Standard conc., } \\
\mu \mathrm{g} / \mathrm{g} \\
\end{array}$ & $\begin{array}{c}\text { Measured conc., } \\
\mu \mathrm{g} / \mathrm{g}^{\mathrm{a}}\end{array}$ & Recovery, \% \\
\hline \multirow{7}{*}{$\begin{array}{l}\text { Conostan Hg Oil, } \\
\text { Lot \#13015 }\end{array}$} & \multirow{7}{*}{100} & 99 & 99 \\
\hline & & 102 & 102 \\
\hline & & 96 & 96 \\
\hline & & 105 & 105 \\
\hline & & 101 & 101 \\
\hline & & 103 & 103 \\
\hline & & 102 & 102 \\
\hline Mean & -- & -- & 101 \\
\hline Std. Dev. & -- & -- & 2.9 \\
\hline $\begin{array}{l}\text { NBS } 1083 \text { (Blank) } \\
+ \text { Hg Spike }\end{array}$ & 48.5 & 51.6 & 106 \\
\hline NBS 1083 (Blank) & -- & $<0.2$ & - \\
\hline
\end{tabular}

a Determined by CVAA with uncertainty of $\pm 10 \%$.

Table 8. Recovery of Selenium from Microwave Digestion of Conostan Oil Selenium, Lot \#12013 ${ }^{\mathrm{a}}$

\begin{tabular}{|c|c|}
\hline Trial & Selenium Recovery, \% \\
\hline \hline Run 1 & 83.5 \\
\hline Run 2 & 90.9 \\
\hline Run 3 & 93.8 \\
\hline Run 4 & 95.0 \\
\hline Mean & 90.8 \\
\hline Std. Dev. & 5.2 \\
\hline
\end{tabular}

${ }^{\text {a }}$ Standard selenium concentration $=100 \mu \mathrm{g} / \mathrm{g}$.

${ }^{b}$ Determined with ICP-AES using a matrix-matched standard for calibration. 


\section{DISCUSSION AND CONCLUSIONS}

The Parr Oxygen Bomb preparations gave disappointing low results when the metal concentrations in solution were compared with the expected values from the reference oils that were processed. The oxygen bomb digestion was thought to be sufficient to completely decompose each oil and absorb the decomposition products in dilute nitric acid, but the data obtained from this system were not satisfactory in that many metals gave recoveries well below $90 \%$. In addition, results were not consistently reproducible. It is possible that, by using different conditions to dissolve the combustion residues, this preparation technique could be optimized [7]. However, because microwave-oven digestates of the same reference materials gave promising results, we did not pursue improvement of the Parr Oxygen Bomb preparations.

The microwave digestion procedure was more effective than the Parr Oxygen Bomb in recovering metals, giving $>90 \%$ recovery for every metal tested. It was also more efficient, since it allowed six samples to be prepared together, whereas oxygen combustion allowed preparation of only one sample at a time. A fiber-optic probe is available for the microwave system to monitor the temperature throughout the digestion $[4,5,6]$. (According to the U.S. EPA Method [3], digestion is complete when the temperature has reached $175^{\circ} \mathrm{C}$ and has been held between $170-180^{\circ} \mathrm{C}$ for approximately 5 minutes [2].) The temperature was not monitored during this study.

Unexpectedly, the microwave digestates exhibited large intensity enhancements in the ICP-AES signals for many metals. When the instrument was calibrated with aqueous standards that did not contain the oil decomposition products, these enhanced intensities produced apparent overrecoveries for the affected metals. By using matrix-matched standards, we were able to eliminate the enhancement interference. After microwave decomposition, the recoveries of all 20 elements (Al, As, B, Ba, $\mathrm{Ca}, \mathrm{Cd}, \mathrm{Cr}, \mathrm{Cu}, \mathrm{Fe}, \mathrm{Hg}, \mathrm{Mg}, \mathrm{Mn}, \mathrm{Mo}, \mathrm{Ni}, \mathrm{Pb}, \mathrm{Se}, \mathrm{Ag}, \mathrm{Ti}, \mathrm{V}, \mathrm{Zn}$ ) 
were within $+/-10 \%$ of the certified values. Because no oil reference material containing certified quantities of radionuclides was available, we were not able to evaluate the suitability of the two sample-preparation methods for radiochemical measurements. However, we anticipate that dissolution behavior of most common radionuclides will be similar to that of the metals we studied, and that reliable radiochemical measurements could be made by using a portion of the solution prepared by microwave digestion. The availability of this method in ACL will help provide reliable, cost-effective waste oil characterization to Argonne's programs. 


\section{ACKNOWLEDGMENT}

The authors would like to express their appreciation to Lynn B. TenKate for her assistance in performing GFAA arsenic and selenium measurements.

\section{REFERENCES}

1. Standard Test Methods of Preparing Refuse-Derived Fuel Samples for Analyses of Metals, American Society for Testing and Materials, Volume 11.04, Test Method ASTME926-88 (1993).

2. Test Methods for Evaluating Solid Waste -- Physical/Chemical Methods, U.S. EPA SW846, Third Edition, Proposed Update II, Method 3051 (1990).

3. Oxygen Bomb Calorimetry and Oxygen Bomb Combustion Methods, Parr Manual No. 120, Parr Instrument Co., Moline, IL (1948).

4. Introduction to Microwave Sample Preparation, H. M. Kingston and L. B. Jassie, Eds., American Chemical Society, Washington, DC (1988).

5. Installation and Operation Manual, Microwave Sample Preparation System, Model MDS-2100, CEM Corp. (1991).

6. E. T. Hasty, S. E. Littan, R. Revesz, "Optimization of Microwave Sample Preparation Methods Using Pressure Feedback Control," presented at the Pittsburgh Conference and Exhibition, 1991.

7. Rule and Proposed Rule, Hazardous Waste: Testing and Monitoring Activities, 40CFR Part 260 et al., Federal Register, Vol. 58, No. 167, pp. 46045-46051 (August 31, 1993). 
Distribution for ANL/ACL-95/1

Internal:

I. Ahmad

O. O. Ajayi

I. Ambats

D. V. Applegate

J. G. Asbury

M. D. Atella

R. W. Bane

D. A. Bass

J. K. Bates

J. E. Battles

N. J. Beskid

M. H. Bhattacharyya

S. K. Bhattacharyya

N. Bhatti

M. Blander

D. H. Bomkamp

A. S. Boparai

D. L. Bowers

B. S. Brown

G. F. Busse

F. A. Cafasso

S. E. Carpenter

Y. I. Chang

L. L. Chromizky

R. F. Coley

J. T. Collins

J. S. Crain

E. J. Croke

J. C. Cunnane

L. W. Deitrich

J. C. Demirgian

C. B. Dennis

M. H. Derbidge

D. R. Diercks

M. L. Dietz

J. D. Ditmars

H. Drucker

F. J. Dudek

B. D. Dunlap

A. J. Dvorak

W. L. Ebert

M. D. Erickson
A. M. Essling

M. A. Essling

D. Ettinger

F. Y. Fradin

N. W. Golchert

A. J. Goldman

D. G. Graczyk

J. W. Gramlich

C. Grandy

D. W. Green

D. M. Gruen

W. H. Gunther

J. E. Harmon

D. A. Haugen

R. R. Heinrich

J. E. Helt

W. F. Henning

J. E. Herceg

I. Hlohowskyj

E. P. Horwitz

H.-S. Huang

E. Huberman

E. A. Huff

D. R. Huff

E. Y. Hwang

M. J. Janik

D. O. Johnson

J. Johnson

P. L. Johnson

T. F. Kassner

S. D. Kent

J. T. Kiely

C. E. Klotz

A. J. Kras

A. R. Krauss

J. R. Krsul

M. Lachman

D. Larson

K. H. Leong

L. G. LeSage

M. A. Lewis

P. C. Lindahl
M. J. Lineberry

C. D. Livengood

C. D. O. Loureiro

F. Markun

V. A. Maroni

J. J. Marr

F. J. Martino

M. L. Mattox

J. R. McCreary

H. F. McFarlane

C. A. Melendres

V. A. Mendez (10)

A. W. Mitchell

D. E. Moncton

L. R. Morss

T. P. Mulcahey

K. M. Myles

H. W. Myron

Z. Nagy

B. W. Nashold

L. A. Neimark

D. M. Nelson

P. A. Nelson

R. D. Nixon

Y. Noyes

J. W. O'Kelley

Y. Orechwa

K. A. Orlandini

D. C. Pancake

K. J. Parish

J.-H. Park

D. C. Parzyck

T. L. Patton

C. V. Pearson

D. R. Pedersen

M. J. Pellin

M. Petrick

K. C. Picel

D. S. Poa

R. B. Poeppel

A. J. Policastro

J. A. Pomykala 
P. D. Postlethwait

Y. L. Qian

A. C. Raptis

D. M. Ray

G. T. Reedy

C. A. Reilly

M. J. Robinet

B. J. Roop

L. E. Ross

C. S. Sabau

N. A. Sacco-Gibson

N. F. Sather

W. W. Schertz

J. B. Schilling

R. M. Schletter

J. F. Schneider

A. Schriesheim

W. J. Shack

G. K. Shenoy

J. G. Sleeth

D. L. Smith

D. L. Smith
F. P. Smith

L. L. Smith

R. K. Smither

C. T. Snyder

B. Srinivasan

R. E. Stajdohar

V. C. Stamoudis

M. J. Steindler

C. M. Stevens

L. M. Stock

W. E. Streets

K. Sugano

T. G. Surles

W. M. Swift

T. A. Taiwo

B. S. Tani

J. D. Taylor

L. B. TenKate

T. TenKate

R. J. Teunis

C. E. Till

D. Tomasko
Z. Tomczuk

A. Travelli

Y. Tsai

J. P. Unik

R. A. Valentin

G. F. Vandegrift

E. Vinokour

D. C. Wade

L. C. Walters

D. W. Warren

R. W. Weeks

J. Wescott

M. L. Wesely

J. M. Williams

R. E. Winans

R. D. Wolson

J. L. Woodring

J. J. Wray

R. A. Wynveen

J. S. Yaeger

R. K. Yoo

TIS Files

\section{External:}

DOE-OSTI (2)

ANL-E Library (2)

ANL-W Library

Manager, Chicago Operations Office, DOE

M. Bollinger, DOE-CH

J. Haugen, DOE-CH

R. E. Lang, DOE-CH

A. L. Taboas, DOE-CH/AAO

Chemical Technology Division Review Committee Members:

E. R. Beaver, Monsanto Company, St. Louis, MO

D. L. Douglas, Consultant, Bloomington, MN

R. K. Genung, Oak Ridge National Laboratory, Oak Ridge, TN

J. G. Kay, Drexel University, Philadelphia, PA

G. R. St. Pierre, Ohio State University, Columbus, $\mathrm{OH}$

J. Stringer, Electric Power Research Institute, Palo Alto, CA

J. B. Wagner, Arizona State University, Tempe, AZ

T. A. Baillieul, Battelle Columbus Laboratories, Columbus, $\mathrm{OH}$

P. Baisden, Lawrence Livermore National Laboratory, Livermore, CA

T. Beasley, U. S. Environmental Measurements Lab., New York, NY

J. Bennett, EG\&G Idaho, Inc., Idaho National Engineering Lab, Idaho Falls, ID 
R. E. Berkeley, U.S. Environmental Protection Agency, Research Triangle Park, NC

R. Bisping, Westinghouse Electric Corporation, Carlsbad, NM

J. A. Borders, Sandia National Laboratories, Albuquerque, NM

R. B. Chessmore, GEOTECH/GJPO, Grand Junction, CO

N. F. Christopher, Martin Marietta Energy Systems, Piketon, OH

G. Clark, Reynolds Electric \& Engineering, Las Vegas, NV

C. E. Coffey, LATO/Rocky Flats Plant, Golden, CO

P. T. Cunningham, Los Alamos National Laboratory, Los Alamos, NM

J. L. Daniel, Battelle Pacific Northwest Laboratory, Richland, WA

H. J. Dewey, Los Alamos National Laboratory, Los Alamos, NM

D. A. Dodd, Westinghouse Hanford Company, Richland, WA

J. G. Dorsey, Martin Marietta Energy Systems, Oak Ridge, TN

P. A. Duhamel, USDOE, Office of Health and Environmental Research, Germantown, MD

C. Elly, U. S. Environmental Protection Agency, Chicago, IL

R. B. Fitts, Oak Ridge National Laboratory, Oak Ridge, TN

I. M. Fox, Woodridge, IL

C. W. Frank, USDOE, Office of Technology Development, Washington, DC

J. Goldstein, USDOE, Office of Health and Environmental Research, Germantown, MD

T. C. Greengard, Rocky Flats Plant, Golden, CO

B. T. Gregg, Allied Signal Aerospace Company, Kansas City, MO

T. Grumbly, USDOE, Office of Environmental Management, Washington, DC

J. Harness, USDOE, Morgantown Energy Technology Center, Morgantown, WV

D. Hunter, EG\&G Rocky Flats Plant, Golden, CO

W. Killian, Ferris State University, Big Rapids, MI

A. G. King, Pacific Northwest Laboratories, Richland, WA

P. Krey, USDOE, Environmental Measurements Labs, New York, NY

C. S. Leasure, Los Alamos National Laboratory, Los Alamos, NM

L. C. Lewis, Westinghouse Idaho Nuclear Company, Idaho Falls, ID

J. Mahoney, West Valley Nuclear Services Company, West Valley, NY

S. Messenger, Morton Arboretum, Lisle, IL

R. W. Morrow, Martin Marietta Energy Systems, Oak Ridge, TN

L. Newman, Brookhaven National Laboratory, Upton, NY

R. D. Oldham, New Brunswick Laboratory, Argonne, IL

M. Pennington, Allied Signal, Kansas City, MO

J. Phillips, Los Alamos National Laboratory, Los Alamos, NM

J. D. Pleil, U.S. Environmental Protection Agency, Research Triangle Park, NC

G. D. Robbins, Martin Marietta Energy Systems, Oak Ridge, TN

C. Ross, U.S. Environmental Protection Agency, Chicago, IL

P. Russ, Lawrence Livermore National Laboratory, Livermore, CA

R. Scott, USDOE, Office of Environmental Quality, Washington, DC

J. Q. Searcy, Sandia National Laboratories, Albuquerque, NM

J. Smith, University of Chicago, Chicago, IL

W. A. Spencer, Westinghouse Savannah River Company, Aiken, SC

J. R. Stetter, Transducer Research, Inc., Naperville, IL

F. D. Stevenson, USDOE, Office of Basic Energy Sciences, Germantown, MD

C. Stroup, Westinghouse Hanford Company, Richland, WA 
L. Sygitowicz, Reynolds Electrical \& Engineering Co., Las Vegas, NV

R. Villarreal, Los Alamos National Laboratory, Los Alamos, NM

W. M. Walsh, Health Research Institute, Naperville, IL

R. J. Wingender, Dexter Corporation, Waukegan, IL

J. Zarret, EG\&G Rocky Flats Plant, Golden, CO 